\title{
THE ANALYSIS OF MULTI- STAKEHOLDERS'VIEW OF ECOPRENEURSHIP STARTUPS: A QUALITATIVE CASE OF KHYBER PAKHTUNKHWA PAKISTAN
}

\author{
Fazaila Shad", Shahid Jan Kakakhel ${ }^{\dagger}$ \& \\ Muhammad Zahid
}

\begin{abstract}
Ecopreneurship is an emerging field of interest in a world grappling with achieving social and economic growth, making frugal use of natural resources as well as preventing pollution simultaneously. In this qualitative study, ten multi-stakeholders of various backgrounds, including the National Incubation Center, Trade Development Authority, Chamber of Commerce \& Industry Peshawar, and non-government organizations were interviewed to explore the concept of ecopreneurship, and to find out the perceptions of multistakeholders about ecopreneurship. The study documented that the stakeholders perceive ecopreneurship as an eco-friendly business. Similarly, the ecopreneurs highlight problems due to unawareness of this concept of environment-friendly business. Likewise, there are several barriers to the sustainability of startups such as limited knowledge, lack of information, lack of awareness by the startup entrepreneurs, and limited funding for promoting sustainable enterprises ecopreneurship. Furthermore, the stakeholders advocate the role of digital technology towards the success of ecopreneurship as it provides a sustainable future through the use of new tools available for startups. The study further discusses theoretical, methodological, and practical implications in the novel concept of ecopreneurship.
\end{abstract}

\footnotetext{
Ph.D. Fellow, Islamia College University Peshawar, Pakistan. Corresponding author Email: fazaila.shad@gmail.com

$\dagger$ Associate Professor, Department of Management Sciences, Islamia College University Peshawar, Khyber Pakhtunkhwa, Pakistan.

* Assistant Professor, Department of Management Sciences, City University of Science and Information Technology Peshawar, Khyber Pakhtunkhwa Pakistan.
} 
Keywords: Ecopreneurship, Ecopreneurs, Multi-stakeholders, Perceptions, Pakistan

\section{Introduction}

The world is facing numerous challenges including social, economic, and environmental. These problems are more shattered due to a lack of connection between concern for societal well-being, economic concern, and environmental consciousness. Therefore, a system that links these three concerns is applauded today, which is ecopreneurship (Schaltegger, 2014). The concept of ecopreneurship seeks to promote and support businesses which are environment friendly. The traditional business models were driven by concerns for-profit and the least concern about the environment. The word eco-entrepreneurship (ecopreneurship) or green entrepreneurship are used interchangeably and has a relatively similar meaning. Entrepreneurship and ecopreneurship are differentiated by entrepreneurs, aiming to gain profit only and ecopreneurship seeks to profit with environmental sustainability (Schaper, 2002). It was Schumpeter (1934) argued that economic development is possible through innovations made by entrepreneurs. Over the past decades, the mounting evidence in the natural environment has suggested that the growth does not go hand in hand with the preservation of nature., Lloss of biodiversity, increasing pollution level, climate change and land degradation are only a few examples of this. Due to all these environmental issues, there is a need for environmental responsibility in entrepreneurship, called ecopreneurship (Cavallo et al., 2019; Galkina \& Hultman, 2016).

The eco-friendly business provides several benefits such as social, economic, and environmental acceptability. Ecopreneurship changes the notion that environmental problems can be dealt with by the government, Non-Governmental Organization (NGOs), and international donors. The aim is to promote an environmentally sensitive product, and at the same time, solve the economic problems(Moghimi \& Alambeigi, 2012). Ecopreneurship focuses on the triple bottom line of economic, equity, and the environment. The ecopreneurs start their business to create eco-friendly markets not only for profit maximization, but also to contribute to the environment. The multi-stakeholders include the government, which is providing tax benefits to ecopreneurs, and non-government organizations, working for green environment and ecopreneurship, suppliers, who are focused on supplying the environmentally friendly material to customers, who are buying green products to promote ecopreneurship (Santini, 2017). The changes that are happening in ecopreneurship are highlighted by academic researches. The ecopreneurship becomes a progressively wide research issue. Ecopreneurs are committed to spreading the gospel of the green vision; today the ecopreneurs are business people, who are interested in gaining a high market 
share in a competitive environment. The business for ecopreneurs has extended the boundaries (Terán-Yépez et al., 2020). The study of ecopreneurship in Pakistan is though highlighted in many types of research; yetstill, there are fewer studies conducted on this issue and the perceptions of the multi-stakeholders in this regard are rarely understand (Saleem et al., 2018).

Ecopreneurship has the potential to be a major force in the overall transition to a more sustainable business paradigm. The environmentresponsible businesses create more opportunities, because many profitable businesses are environment conscious and constantly working for economic advantages through going green. There is a need to promote ecopreneurship in Khyber Pakhtunkhwa; there are fewer studies conducted on this important issue. Tthe new startups in Khyber Pakhtunkhwa need proper policies and guidelines, which are not clear yet about environment-friendly business. The future generations for the success of ecopreneurship requiresd higher education and connectivity (Mubarak et al., 2019). The objective of this study is to identify the multi-stakeholders view of ecopreneurship. The question, therefore, underpinning this paper and the research informing it is what the perceptions of multi-stakeholders about ecopreneurship are.?

The study brings several theoretical, methodological, and practical implications for the different stakeholders such as entrepreneurs, small and medium enterprises development authority (SMEDA), and other regulatory bodies.

The paper is outlined in a literature review, methodology, findings and analysis, and discussion and conclusion are discussed in the next sections.

\section{Literature Review}

\section{Theoretical Framework- Institutional Theory}

The current study uses institutional theory as a theoretical framework (DiMaggio \& Powell, 1983). The institutional theory sheds light on the deeper and more resilient aspects of the specific institutions (the social structure). The theory also postulates that how these entrepreneurial ecosystems become firmly established and construct reality for the individual and organizations, to govern their behaviors and clarify what can and cannot be acted upon can be acted upon and what cannot (Wakkee et al., 2019). The entrepreneurs try to explore how they transform the existing and prevalent norms, rules, structures, and routines to create the novel ones, regardless of path dependencies and complexities involved. The authors further noted that to combine the concepts of entrepreneurship, and institutions' insight can be collected into how change is enacted despite pressures for continuity and into "how and why certain novel organizing solutions - new practices or new organizational forms, for example - come into existence and become well established over time". 


\section{The Concept of Ecopreneurship}

There are many definitions of entrepreneurship and ecopreneurship provided by different scholars. The first challenge is to find out the unique and most acceptable definition of ecopreneurship. This challenge aroused because firstly, the issue of ecopreneurship is complex and under investigation., Ssecondly, there is a lack of consensus on what constitutes an entrepreneur (Chell et al., 1991). This lack of consensus on the definition of entrepreneurship makes it harder to define ecopreneurship. It is suggested that ecopreneurs are entrepreneurs who run a business based on principles and sustainability (Kirkwood \& Walton, 2010). The interest in ecopreneurship has significantly improved the number of academic outcomes because ecopreneurs can be considered as a change drivers. Moreover, the issues of the environment have been progressively incorporated into text on entrepreneurship (Schaper, 2002). The author describes eco-entrepreneurship as the process which promoted entrepreneurship by putting together the role of startups, business venturing, and institution involvement. Entrepreneurs solely focus on profit while ecopreneurs adopted different paradigms, solving the problems of society through business innovation (Rice, 2009). Ecopreneurs are not only working for-profit, but they also pay attention to the underlying green values (Kirkwood \& Walton, 2010).

Ecopreneurship was influenced by the variety of disciplines (such as political geography, economics, politics, urban studies, sociology, business ethics tourism research, environmental policy, etc.), but mainly, the study of ecopreneurship is developed at the intersection of studies of entrepreneurship and environmental policies (Galkina \& Hultman, 2016). The ecopreneurship represents one of the four directions within the entrepreneurship domain. Ffirstly, it is related to the traditional economy relates to starting a business for economic gains. Secondly, it is becoming intrapreneurship or corporate entrepreneurship that can be found in large companies that aimed to create new business products (Schaltegger, 2002). The third is the creation and management of non-profit organizations called social entrepreneurship. The forth is associated with environmentally responsible business practices and values called green entrepreneurship or ecopreneurship (Galkina \& Hultman, 2016).

A wide branch of research has investigated the characteristics of entrepreneurs; therefore, research on entrepreneurship is endless. Some authors attached psychological and sociological characteristics with entrepreneurship (Gibb, 1987). Entrepreneurs are those who have an outstanding attitude towards leadership and risk., Ffurthermore, entrepreneurs have a high degree of tolerance and ambiguity,; because they have a strong need for achievement. Therefore, entrepreneurship is a complex combination of many approaches (Saleem et al., 2018). There is 
macro tendency shown in the wider field of entrepreneurship by various researchers; some provide a detailed overview of the push and pull ecopreneurs drivers whilst other work aimed to outline the characteristics of ecopreneurs. The distinctive trait of ecopreneurs is to shape the face of their companies by improving their image and working not only for the company but for the community as the whole (Kirkwood \& Walton, 2010). Some researchers underlined ecopreneurship as a choice between making a profit and going green; by combining the desire to make the environment better with money (Linnanen, 2005). Therefore, over the years, the context has changed and there is global awareness about ecopreneurship; the situation is improved because scholars have interlinked the sustainability and competitive advantage (Kramer \& Porter, 2011). Ecopreneurs can influence the environment with their behaviors, because entrepreneurs have a strong linkage with the firm's external environment, furthermore, entrepreneurs can shape their company from the outset (Schaltegger, 2002).

Galkina and Hultman (2016) assess ecopreneurship through social movements. The three-domain areas were used to assess the ecopreneurship including mobilization, differentiation, and legitimacy building. Ecopreneurship is still in the early stages of development as an academic study; it further requiresd theoretical contributions. The ecopreneurship study is still open for contributions from other fields of study to formulate a proper policy and strategy for ecopreneurship and to build a more solid foundation of ecopreneurship as an academic study. According to Santini (2017), the ecopreneurship is a new topic of emergence the study highlight the research outputs regarding ecopreneurship, and provides an extensive literature review of ecopreneurship. The study provides the typologies and motivation of entrepreneurs, and it also focuses on the relationship between ecopreneurship and agri-business to outline the issues. To and further investigate to extend the business, the paper discusses the traits of ecopreneurship and gives an in-depth insight to the ecopreneurship trends and practices its limitations and characteristics. ItAnd also providesd the ecopreneurship issues which are to be addressed in future research.

\section{Methodology}

A qualitative research approach was adopted in this study of ecopreneurship because qualitative study provides in-depth knowledge of the study (Silverman, 2016). This empirical study is conducted to find out the perceptions of multi-stakeholders about ecopreneurship. This qualitative study undertook the semi-structured interviews from ten ecopreneurs. The study is focused on Khyber Pakhtunkhwa in Pakistan to explore ecopreneurship from stakeholders' perspectives. We selected Khyber Pakhtunkhwa to study as a case because ecopreneurship is a promising research stream, as it is considered as a panacea for solving environmental 
problems. The ecopreneurship research also establishes strong links with governmental institutions, local communities, non-governmental organizations and supplier groups, etc. there this study of ecopreneurship that will cover some multi-stakeholders' views about ecopreneurship and how ecopreneurship works in the real environment. The participants of the study were selected using a maximum variation sampling technique. In maximum variation sampling technique was used instead of seeking representative through equal probability., Tthis technique includes a wide range of extremes (Patton et al., 2008). The aggregate answers of a selected people are close to the whole population. The data wasare recorded using a Samsung galaxy voice recorder. The recorded data wasis then transcribed. Data transcription is an important necessary component of a qualitative study in which, audio or video recording is translated into words. After the transcription, the data wasare analyzed using content analysis. The content analysis wasis used to determine certain themes and concepts (Berelson, 1952). The process was done using open coding, axial coding. And in the end, the results have been will be interpreted.

\section{Findings and Analysis}

In this section the results of the data gathered are presented, the findings and analysis of data in this section presented the list of the multistakeholders, and their perceptions about ecopreneurship.

\section{Table 1: List of participants}

\begin{tabular}{cllc}
\hline $\begin{array}{c}\text { Participant } \\
\text { No. }\end{array}$ & Position & Department & No \\
\hline 1 & Manager & National Incubation Center (NIC) & 1 \\
2 & Official & National Incubation Center (NIC) & 1 \\
3 & Official & National Incubation Center (NIC) & 1 \\
4 & Chief officer & SMEDA Peshawar & 1 \\
5 & State Bank of & Finance Manager & 1 \\
6 & Pakistan & Local community & 2 \\
7 & CEO & CMDO (Non-governmental organization) & 1 \\
8 & General Secretary & Chamber of Commerce and Industry & 1 \\
9 & Chairman & Peshawar & Trade Development Authority Pakistan \\
\hline
\end{tabular}




\section{Perceptions of Multi-Stakeholders about Ecopreneurship}

Ecopreneurship has a deep effect on invoking society towards sustainability. The multi-stakeholders are putting their efforts into promoting ecopreneurship (Galkina \& Hultman, 2016). Ecopreneurs search for green strategic innovations, and also encourage green networking in the community; they also use social ecopreneurship as an extraordinary motivator.

Sustainability of the environment is crucial and it requiresd proper financing., It Sustainability of the environment is growing concern and the best business is a greener, eco-friendly business, and more efficient business. It is noted that consumers want to work with sustainable companies because environment-friendly companies have the best reputation, the finance department of State bank participant 4 stated:

"We encourage and appreciate ecopreneurship because it will benefit the whole society. State bank launches a credit guarantee scheme for entrepreneurs and finances young entrepreneurs from all over Pakistan. Entrepreneurs who are more concerned about the environment are our preference because they are working for a better environment which is beneficial for all of us. Mostly ecopreneurs are unaware of the credit financing though they wanted to start an eco-friendly business due to lack of information and awareness many startups are not initialized."

There is a need of motivation and support to start a business official National Incubation Center (NIC) Peshawar participant no 3stated:

"In my opinion, ecopreneurship represents the principles of entrepreneurship, which is applied to create a good environment and sustainability; first of all, it is important to understand that as an entrepreneur have some ecological and social concerns. I am working in National incubation center for 3 years what I noticed is that startup success is related to a broad set of skills and dedication towards the business. Many entrepreneurs want their business to be successful in a short period and what I have seen is that they are more inclined towards the money-making rather than ecopreneurship, I must say they are traditional entrepreneurs only because the perception is giving something for free cannot benefit the business though in a long term this is not valid."

There are many responsibilities of entrepreneurs towards the environment which cannot be neglected., Pparticipant no 2-program official of National Incubation Center (NIC) stated:

"National incubation aims to build a thriving ecopreneurs system and to support the innovative product-based tech startups. We are 
trying to help startups. We nourished entrepreneurship in almost all the domains regarding businesses that change the entrepreneurial landscape of the region because consumers care about CSR. I believe our actions can make a big difference in the world. In Peshawar, mostly the people as Pashtuns and we see a large number of men Ecopreneurs but a smaller number of women are doing entrepreneurship still women working for the eco-friendly environment are small in number, so the Peshawar market is a bit different and environment opportunity are not so easy to grasp."

The manger National Incubation Center (NIC) the participant no 1further added:

There are lots of environmental problems in Pakistan as we know: water pollution, air pollution, noise pollution, climate change, natural disasters, and desertification. The eco-friendly business aimed to sustain the environment by using less water, energy, and raw material while cutting carbon emissions. This type of business minimizes the strain on natural resources. As being a project coordinator of startups, many of eEcopreneurs come with fantastic ideas and we encourage the young entrepreneurs to be conscious about the environment around".

Eco entrepreneurship and ecopreneurship areis the nexus of innovation, concern for the environment, and entrepreneurship. The innovation or business with an initiative to clean for the environment equally benefits the environment around us. The participant no 4 chairmen SMEDA stated:

"Through the growth of the competitive SME sector, we provide the best environmental and support services and we facilitate the business development services. The idea of ecopreneurship is appreciable and we are helping the SMEs to be more focused on environmental issues as well."

Ecopreneurship is a human innovation to expand the supply of natural resources and to improve the environment quality the participant no 9 Director TDAP stated:

"We promote Ecopreneurs and their good work throughout the globe, we Participate in 120 to 140 international trade exhibitions annually. Eco-friendly business is the need of the time because in Pakistan we are facing so many environmental problems."

Ecopreneurship is the answer to many problems we are facing here in this region. We should encourage young Ecopreneurs to come forward and 
work for the environment. General Secretary Chamber of Commerce and industry participant no 8 stated:

"In the Chamber of Commerce \& Industry Peshawar more than thousand men entrepreneurs are working and roundabout, five hundred women entrepreneurs are registered though business and entrepreneurship are all about money-making, many of the entrepreneurs registered here are working for humanity and environment as well, as I know them personally so the problem in this region is that sometimes you are not appreciated for your work and as we know that competition is getting tough in the market so the more you are concern about your consumers the more they will be loyal towards you."

The role of NGOs in ecopreneurship is being understood in terms of their strengths and weaknesses in entrepreneurship development. The CEO Community Motivation \& development organization Peshawar Participant no 7stated:

"As all of us know Non-government organization is growing in number and getting them a place in society. We are supporting many women entrepreneurs in different regions and we promote ecopreneurship as we are given free education to many entrepreneurs and we are promoting eco-friendly business plans.

Consumers play a large role in ecopreneurship because consumers are concerned about the way their choice of products and purchase affect the environment. Companies can get a competitive advantage through ecopreneurship. Consumer participant 6 stated:

"I think it is important for a company to design environmentallyconscious products because many of the consumers pay attention to the product's environmental impact. The main reason I buy ecofriendly products is the health benefits, preservation of the environment, and also ethical aspects of production. Ecopreneurship is important because many people are now aware of the growing need for more products."

Another consumer also stated:

"I believe if consumers decided to buy only eco-friendly products and purchase only those products which equally benefit for the environment, we can promote ecopreneurship"

\section{Discussion and Conclusion}

Ecopreneurship is a niche within Entrepreneurship; ecopreneurship is related to the activities that clean the environment and also, to carry out 
business activities, Bbecause of increasing interest in environmental issues, the multi-stakeholders are now more accountable (Dixon \& Clifford, 2007). Through ecopreneurship, specific environmental problems can be solved. Furthermore, this study will provide a framework of ecopreneurship, which will help the business startups in adopting an ecopreneurs approach to business. Pakistan is facing many environmental problems such as climate change, overpopulation, water scarcity, energy crisis, and so on; the answer to this entire problem is ecopreneurship (Schaltegger, 2002). There is an increasing amount of interest in environmental issues; therefore, many startup businesses are conscious of environmental issues as well. The ecofriendly business is a need of time due to more profit and productivity. Because eco-friendly business provides a lot of benefits mutually, there are many advantages of ecopreneurship because it not only provides profit, but also improves the image of the company and businesses. People buy more eco-friendly products because of a feasible environment. Green business or ecopreneurship is still an attractive choice for many startups (Isaak, 2017). The sustainability of nature maximizes the profit and save the environment.

However, there are many barriers faced by ecopreneurship as there are several barriers to the sustainability of startups such as limited knowledge, lack of information, lack of awareness by tart up entrepreneurs, and limited funding for promoting sustainable enterprises (Cohen, 2006). Similarly, there is a need to solve environmental issues through an entrepreneurial approach. For thise reason,purpose ecopreneurs are the champions of sustainability and started their businesses for environmental orientations and their motivations. The environment is systematically scanned by ecopreneurs to obtain information about the opportunities and to interact with the environment (Crijns et al., 2008). Thus, ecopreneurs are working for the environment and going green rather than profit-making. Many of the stakeholders perceive that ecopreneurship is the need of the time and is an important activity, because there are many problems faced by eEcopreneurs due to negative response and lack of awareness about the importance of ecopreneurship it is difficult for Ecopreneurs to operate actively (Galkina \& Hultman, 2016). The reason is many people think of a nonprofit business as negative growth of the business itself. Thus, ecopreneurship needs support and motivation to operate at all levels, especially the new startups (Nicotra et al., 2018).

\section{References}

Berelson, B. (1952). Content analysis in communication research.

Cavallo, A., Ghezzi, A., \& Balocco, R. (2019). Entrepreneurial ecosystem research: present debates and future directions. International Entrepreneurship and Management Journal, 15(4), 1291-1321. https://doi.org/10.1007/s11365-018-0526-3 
Chell, E., Haworth, J., \& Brearley, S. (1991). The entrepreneurial personality (Vol. 16). London: Routledge.

Cohen, B. (2006). Sustainable valley entrepreneurial ecosystems. Business Strategy and the Environment, 15(1), 1-14.

Crijns, H., Laveren, E., \& Smallbone, D. (2008). Entrepreneurship, sustainable growth and performance: Frontiers in European entrepreneurship research. Edward Elgar Publishing.

Dixon, S.E.A., \& Clifford, A. (2007). Ecopreneurship - A new approach to managing the triple bottom line. Journal of Organizational Change Management, 20(3),

326-345. https://doi.org/10.1108/09534810710740164

Galkina, T., \& Hultman, M. (2016). Ecopreneurship-Assessing the field and outlining the research potential. Taylor \& Francis, 23(1), 58-72. https://doi.org/10.1080/13215906.2016.1188716

Gibb, A.A. (1987). Enterprise culture-its meaning and implications for education and training. Journal of European Industrial Training.

Isaak, R. (2017). Green logic: Ecopreneurship, theory and ethics.

Kirkwood, J., \& Walton, S. (2010). How ecopreneurs' green values affect their international engagement in supply chain management. Journal of International Entrepreneurship, 8(2), 200-217.

Kramer, M.R., \& Porter, M. (2011). Creating shared value. FSG.

Linnanen, L. (2005). An insider's experiences with environmental entrepreneurship. Making Ecopreneurs: Developing Sustainable Entrepreneurship, 72-88.

Moghimi, S.M., \& Alambeigi, A. (2012). Government Facilitator Roles and Ecopreneurship in Environmental NGOs.

Mubarak, A., Jangkung, H.M., \& Hartono, S. (2019). The influence of entrepreneurship characteristics and competencies on farmers' entrepreneurial intentions in the border region of North Borneo. IOP Conference Series: Earth and Environmental Science, 250(1), 12109.

Nicotra, M., Romano, M., Del Giudice, M., \& Schillaci, C.E. (2018). The causal relation between entrepreneurial ecosystem and productive entrepreneurship: a measurement framework. Journal of Technology Transfer, 43(3), 640-673. https://doi.org/10.1007/s10961-017-9628-2

Patton, R.M., Beckerman, B., \& Potok, T.E. (2008). Analysis of mammography reports using maximum variation sampling. Proceedings of the 10th Annual Conference Companion on Genetic and Evolutionary Computation, 2061-2064.

Rice, G. (2009). Book review-“Social-uplift environmentalism” and what it means for entrepreneurship, investing, and consumer engagement. Global Business and Organizational Excellence, 29(1), 91-95.

Saleem, F., Adeel, A., Ali, R., \& Hyder, S. (2018). Intentions to adopt ecopreneurship: moderating role of collectivism and altruism. 
Santini, C. (2017). Ecopreneurship and ecopreneurs: Limits, trends and characteristics. Sustainability, 9(4), 492.

Schaltegger, S. (2002). A Framework for Ecopreneurship. Greener Management International, 38.

Schaltegger, S. (2014). A Framework for Ecopreneurship. Greener Management International. https://doi.org/10.9774/gleaf.3062.2002.su.00006

Schaper, M. (2002). The essence of ecopreneurship. Greener Management International, 26-30.

Silverman, D. (2016). Qualitative research. Sage.

Terán-Yépez, E., Marín-Carrillo, G.M., Casado-Belmonte, M. del P., \& Capobianco-Uriarte, M. de las M. (2020). Sustainable entrepreneurship: Review of its evolution and new trends. Journal of Cleaner Production, 252. https://doi.org/10.1016/j.jclepro.2019.119742 